УДК 351.746 .1

DOI https://doi.org/10.32836/2310-9653-2020-3.16

\author{
Л. В. Бобрицький, кандидат юридичних наук, \\ доцент кафедри публічного управління \\ та адміністрування Інституту підготовки кадрів \\ державної служби зайнятості України
}

\title{
КОНТРОЛЬ ЗА ДІЯЛЬНІСТЮ СЕКТОРА БЕЗПЕКИ, ЩО ЗДІЙСНЮЄТЬСЯ КАБІНЕТОМ МІНІСТРІВ УКРАЇНИ
}

Із проголошенням Незалежності України Верховною Радою було прийнято низку законодавчих актів щодо забезпечення національної безпеки і оборони країни. Водночас виникла необхідність у здійсненні ефективного демократичного ичивільного контролю над усіма силовими структурами держсави. Це створило передумови для подальшого розвитку і вдосконалення механізмів публічного управління в інтересах національної безпеки держави. У Конститучії України понятття демократичного иивільного контролю у сфері національної безпеки і оборони відсутнє, такі повноваження визначені у Президента України та у органів державної влади.

Питання здійснення демократичного иивільного контролю за сектором безпеки набули нового важливого значення з початку 2014 року, коли Російська Федерація розпочала проти Украӥни відкриту збройну агресію. Таким чином, наукові розробки у иій иарині потребують поглибленого аналізу й додаткового дослідження.

В умовах розбудови сучасного громадянського суспільства демократичний ичиільний контроль над сектором безпеки постає невід'ємною, важливою ознакою демократії, такою ж, як і свобода слова, дотримання прав людини та громадянина.

Відповідно до «Стратегії наиіональної безпеки України», затвердженої Указом Президента України від 26 травня 2015 року № 287/2015, основними напрямками державної політики наџіональної безпеки України є: удосконалення державної системи стратегічного планування, створення єдиної системи моніторингу, аналізу, прогнозування та прийняття рішень у сфері національної безпеки і оборони, забезпечення ефективної координації та функиіонування єдиної системи ситуаційних иентрів профільних органів державної влади сектору безпеки і оборони; якісне вдосконалення системи демократичного цивільного контролю над органами сектору безпеки і оборони та посилення парламентського контролю у цій сфері.

Ураховуючи, щзо Україна взяла на себе міжнародні зобов'язання встановити демократичний контроль над силовими структурами держави, предметом нашого наукового дослідження має бути аналіз системи контролю, що здійснюється Кабінетом Міністрів України у сфері національної безпеки й оборони краӥни.

Ключові слова: начіональна безпека, демократичний иңвільний контроль, сектор безпеки $і$ оборони, контроль Кабінетом Міністрів України.

\section{V. Bobrytskyi. Control over the activities of the security sector carried out by the Cabinet of Ministers of Ukraine}

With the proclamation of Ukraine's independence, the Verkhovna Rada adopted a number of legislative acts to ensure national security and defense. At the same time, there was a need for effective democratic civilian control over all law enforcement agencies. This created the preconditions for further development and improvement of public administration mechanisms in the interests of national security. However, the fact that the Constitution of Ukraine lacks the concept of democratic civilian control in the field of national security and defense, in turn, such powers are defined by the President of Ukraine and public authorities.

The issue of democratic civilian control over the security sector has gained new importance since the beginning of 2014, when the Russian Federation launched an open armed aggression against Ukraine. Thus, scientific developments in this area require in-depth analysis and additional research.

In the context of building a modern civil society, democratic civilian control over the security sector is an integral, important feature of democracy, as is freedom of speech and respect for human and civil rights.

In accordance with the "National Security Strategy of Ukraine" approved by the Decree of the President of Ukraine of May 26, 2015 № 287/2015. The main directions of the state national security policy of Ukraine are, among others: improvement of the state system of strategic planning, creation of a unified system of monitoring, analysis, forecasting and decision-making in the field of national security and defense, ensuring effective coordination and functioning of a unified system of situational centers. security and defense; qualitative improvement of the system of democratic civilian control over the bodies of the security and defense sector and strengthening of parliamentary control in this area.

Given that Ukraine has undertaken international obligations to establish democratic control over the security forces of the state, the subject of our research should be the analysis of the control system carried out by the Cabinet of Ministers of Ukraine in the field of national security and defense. Ukraine

Key words: national security, democratic civilian control, security and defense sector, control by the Cabinet of Ministers of

Постановка проблеми. Із проголошенням у серпні 1991 року Незалежності України Верховна рада розпочала активну роботу із прийняття законодавчих актів щодо забезпечення безпеки і оборони країни. Водночас виникла необхідність у здійсненні ефективного контролю над усіма силовими структурами. Це створило

\section{(C) Л. В. Бобрицький, 2020}


передумови для подальшого розвитку й вдосконалення механізмів публічного управління в інтересах національної безпеки держави.

Слід зауважити, що в Конституції України [2] відсутнє поняття демократичного цивільного контролю у сфері національної безпеки, але такі повноваження є в Президента України та в органів державної влади.

На початку 2014 року, коли Російська Федерація розпочала проти України відкриту збройну агресію, питання здійснення демократичного цивільного контролю за сектором безпеки набули нового важливого значення. Отже, наукові розробки у цій царині потребують поглибленого аналізу й додаткового дослідження.

Аналіз останніх досліджень і публікацій. Подальший розвиток і вдосконалення сектору безпеки і оборони України потребує ефективного контролю з боку Кабінету Міністрів України. Цю проблематику у своїх наукових розробках досліджували В.Т. Білоус, О.С. Бодрук, П.В. Ворона, В.П. Горбулін, А.С. Гриценко, Г.П. Ситник, А.І. Семенченко, А.Б. Качинський, В.А. Ліпкан, В.О. Шамрай та інші.

Так, П.В. Ворона визначає, що цивільний контроль над силовими структурами держави, як, наприклад, максимальне залучення органів публічної влади до управління силовими структурами за мінімальної участі останніх у політичному керівництві країною, часто виражається в управлінні цивільними особами силовими структурами та $є$ управлінським інструментом демократичного режиму в сучасних умовах, хоча в сучасних демократичних державах дуже поширена участь військових в окремих сферах життя й діяльності суспільства та існує потреба в армії, інших силових структурах держави, в певному ступені професійної автономії [12].

Водночас у теорії державного управління питання демократичного цивільного контролю залишається проблемним та актуальним і потребує додаткового й грунтовного аналізу.

Мета статті. Метою нашої наукової розвідки є аналіз системи контролю, що здійснюється Кабінетом Міністрів України у сфері національної безпеки й оборони держави.

Виклад основного матеріалу. Україна взяла на себе міжнародні зобов'язання встановити демократичний контроль над силовими структурами, що було зафіксовано в таких нормативно-правових актах: «Партнерство заради миру: Рамковий документ» [3], «Хартія про особливе партнерство між Україною та НАТО» [13], а також «Кодекс поведінки стосовно воєнно-політичних аспектів безпеки» [1].

Демократичний цивільний контроль над сектором безпеки є невід’ємною, важливою ознакою демократії, такою ж, як і свобода слова, дотримання прав людини та громадянське суспільство.

Відповідно до «Стратегії національної безпеки України» [11], затвердженої Указом Президента України від 26 травня 2015 року № 287/2015, основними напрямками державної політики національної безпеки України є: вдосконалення державної системи стратегічного планування, створення єдиної системи моніторингу, аналізу, прогнозування та прийняття рішень у сфері національної безпеки і оборони, забезпечення ефективної координації та функціонування єдиної системи ситуаційних центрів профільних органів державної влади сектору безпеки і оборони; якісне вдосконалення системи демократичного цивільного контролю над органами сектору безпеки і оборони, посилення парламентського контролю у цій сфері [11].

Законом України «Про демократичний цивільний контроль над Воєнною організацією і правоохоронними органами держави» [6] були визначені система та суб’єкти контролю. Система цивільного контролю над Воєнною організацією і правоохоронними органами держави складалась із: парламентського контролю; контролю, здійснюваного Президентом України; контролю з боку органів виконавчої влади та органів місцевого самоврядування.

Серед суб'єктів цивільного контролю над Воєнною організацією і правоохоронними органами держави визначено також і Кабінет Міністрів України [6].

До Повноваження Кабінету Міністрів України у здійсненні контролю, згідно із цим Законом, належить: здійснення контролю за експортом озброєнь та військової техніки, стратегічних матеріалів, технологій та продукції подвійного призначення; здійснення контролю за дотриманням у Збройних Силах України, інших військових формуваннях, правоохоронних органах земельного, податкового, господарського, трудового, житлового законодавства, законодавства 3 охорони довкілля; з метою узагальнення відомостей про порушення прав чи законних інтересів осіб правоохоронними органами та підготовки керівникам таких органів обов'язкових до розгляду рекомендацій, у тому числі про необхідність вжиття відповідних заходів щодо притягнення винних осіб до відповідальності [6].

Із прийняттям Верховною Радою України Закону України «Про національну безпеку України» [9] визначається й поняття сектору безпеки і оборони України, що складається з чотирьох взаємопов'язаних складових частин: сили безпеки; сили оборони; оборонно-промисловий комплекс; громадяни та громадські об'єднання, які добровільно беруть участь у забезпеченні національної безпеки.

Функції та повноваження складових сектору безпеки і оборони визначаються законодавством України.

До складу сектору безпеки і оборони входять: Міністерство оборони України, Збройні Сили України, Державна спеціальна служба транспорту, Міністерство внутрішніх справ України, Національна гвардія України, Національна поліція України, Державна прикордонна служба України, Державна міграційна служба України, Державна служба України з надзвичайних ситуацій, Служба безпеки України, Управління державної охорони 
України, Державна служба спеціального зв’язку та захисту інформації України, Апарат Ради національної безпеки і оборони України, розвідувальні органи України, центральний орган виконавчої влади, що забезпечує формування та реалізує державну військово-промислову політику.

Інші державні органи та органи місцевого самоврядування здійснюють свої функції із забезпечення національної безпеки у взаємодії з органами, які входять до складу сектору безпеки і оборони [9].

Конституцією і законодавством України на Кабінет Міністрів України покладено певні функції зі здійснення контролю за силовими структурами держави.

Відповідно до Конституції Кабінет Міністрів України: здійснює заходи щодо забезпечення обороноздатності і національної безпеки України, громадського порядку, боротьби зі злочинністю, а також спрямовує і координує роботу міністерств, інших органів виконавчої влади [2].

У свою чергу, Законом України Про Кабінет Міністрів України визначені основні завдання Кабінету Міністрів України, до яких належить спрямування та координація роботи міністерств, інших органів виконавчої влади, здійснення контролю за їх діяльністю. Кабінет Міністрів України здійснює постійний контроль за виконанням органами виконавчої влади Конституції України та інших актів законодавства України, вживає заходів щодо усунення недоліків у роботі зазначених органів [8].

Після прийняття Верховною Радою України Закону України «Про національну безпеку України» [8] було визначено, що Кабінет Міністрів України відповідно до статей 113, 116, 117 Конституції і законів України здійснює контроль за дотриманням законодавства та реалізацією державної політики у сферах національної безпеки і оборони, звітує з цих питань перед Президентом України і Верховною Радою України.

Кабінет Міністрів України забезпечує цивільний контроль за діяльністю Збройних Сил України, Державної спеціальної служби транспорту, Національної поліції України, Національної гвардії України, Державної прикордонної служби України, Державної служби України з надзвичайних ситуацій, Державної міграційної служби України, Державної служби спеціального зв'язку та захисту інформації України, інших органів виконавчої влади, які входять до сектору безпеки і оборони України.

Центральні органи виконавчої влади, що мають у підпорядкуванні утворені відповідно до законів України військові формування, розвідувальні та правоохоронні органи:

1) забезпечують цивільний контроль у межах своїх повноважень;

2) створюють необхідні умови для здійснення іншими суб'єктами цивільного контролю передбачених законами повноважень;

3) забезпечують об'єктивне і своєчасне інформування Президента України, Верховної Ради України, Кабінету Міністрів України, Ради національної безпеки і оборони України про стан справ у підпорядкованих органах сектору безпеки і оборони;

4) інформують із цих питань громадськість у порядку, визначеному цим та іншими законами України [8].

Слід зауважити, що питання контрою за сектором безпеки Кабінетом Міністрів України знайшли відображення й інших законодавчих актах.

Згідно із Законом України «Про оборону України» [10] Кабінет Міністрів України контролює виконання законів у сфері оборони, здійснює відповідно до законів інші заходи щодо забезпечення обороноздатності України, координує і контролює їх виконання та несе, в межах своїх повноважень, відповідальність за забезпечення оборони України [10].

Згідно із Законом України «Про Збройні Сили України» [7] Кабінет Міністрів України: здійснює відповідно до Конституції і законів України контроль за діяльністю Збройних Сил України та інші повноваження щодо забезпечення бойової, мобілізаційної готовності, боєздатності і функціонування Збройних Сил України [7].

Згідно із Законом України «Про Державну спеціальну службу транспорту» [5] Державна спеціальна служба транспорту є спеціалізованим військовим формуванням, що входить до системи Міністерства оборони України, призначеним для забезпечення стійкого функціонування транспорту в мирний час та в особливий період.

Кабінет Міністрів України:

1) здійснює управління відповідно до Конституції і законів України Державною спеціальною службою транспорту та контроль щодо їі функціонування і забезпечення постійної готовності до виконання завдань у мирний час та особливий період;

2) розробляє і здійснює державні програми розвитку Державної спеціальної служби транспорту в порядку, встановленому законом, у межах своєї компетенції здійснює контроль за виконанням цих програм;

3) визначає органи, які здійснюють державний нагляд за безпечним веденням робіт особами, які проходять військову службу в органі управління Державною спеціальною службою транспорту, бригадах, полках, окремих батальйонах, підрозділах охорони, органах забезпечення, навчальному центрі, закладах, на підприємствах та в установах, що входять до складу Державної спеціальної служби транспорту [5].

Згідно із Законом України «Про Державну службу спеціального зв’язку та захисту інформації України» [4] Державна служба спеціального зв’язку та захисту інформації України є державною системою урядового 
зв'язку - системою спеціального зв’ язку, що функціонує в інтересах здійснення управління державою у мирний час, в умовах надзвичайного стану та в особливий період із забезпеченням додержання вимог законодавства під час передавання, приймання та оброблення інформації, що містить державну таємницю;

Контроль за діяльністю Державної служби спеціального зв’язку та захисту інформації України здійснюється в порядку, визначеному Конституцією та законами України. Діяльність Державної служби спеціального зв’язку та захисту інформації України спрямовується та координується Кабінетом Міністрів України. Державна служба спеціального зв’язку та захисту інформації України підконтрольна Верховній Раді України.

Із питань, пов’язаних із забезпеченням національної безпеки та оборони України, Державна служба спеціального зв’язку та захисту інформації України підпорядковується і підконтрольна Президентові України.

Голова Державної служби спеціального зв’язку та захисту інформації України щороку до 20 лютого подає письмову інформацію:

1) Президенту України про діяльність Державної служби спеціального зв’язку та захисту інформації України з основних питань, пов'язаних із забезпеченням національної безпеки України;

2) Верховній Раді України про виконання покладених на Державну службу спеціального зв'язку та захисту інформації України завдань, додержання законодавства, прав і свобод людини і громадянина, інших питань;

3) Кабінету Міністрів України звіт про діяльність Державної служби спеціального зв'язку та захисту інформації України [4].

Висновки з даного дослідження і перспективи подальших розвідок у даному напрямку. Отже, на підставі викладеного можемо дійти висновку, що, зважаючи на те, як стратегічні рішення сектору безпеки України, наприклад, про початок або припинення воєнних дій, можуть вплинути на життя усієї країни, контроль, що здійснюється Кабінетом Міністрів України за сектором безпеки, завжди залишається предметом розгляду як невід’ємна складова частина механізму державного управління.

\section{Список використаних джерел:}

1. Кодекс поведінки стосовно воєнно-політичних аспектів безпеки\{Джерело: сайт OБСЄ. URL : https://www.osce.org/uk/node/253046?download=true\}. URL : https://zakon.rada.gov.ua/laws/show/994_116.

2. Конституція України, прийнята на п'ятій сесії Верховної Ради України 28 червня 1996 року. Відомості Верховної Ради України (ВВР). 1996. № 30, ст. 141. URL : https://zakon.rada.gov.ua/laws/show/254к/96-вр.

3. Партнерство заради миру Рамковий документ від 08 лют. 1994 р. Дипломатический вестник. № 13-14. 1994. С. 32-33. URL : https://zakon.rada.gov.ua/laws/show/950_001.

4. Про Державну службу спеціального зв'язку та захисту інформації України, Закон України від 23 лют. 2006 р. № 3475-IV. Відомості Верховної Ради Украӥни (ВВР). 2006. № 30. Ст. 258. URL : https://zakon.rada.gov.ua/laws/show/3475-15.

5. Про Державну спеціальну службу транспорту : Закон України від 5 лют. 2004 р. № 1449-IV. Biдомості Верховної Ради України (ВВР). 2004. № 19. Ст. 269). URL : https://zakon.rada.gov.ua/laws/show/1449-15.

6. Про демократичний цивільний контроль над Воєнною організацією і правоохоронними органами держави : Закон України від 19 черв. 2003 р. № 975-IV. Відомості Верховної Ради Украӥни (ВВР). 2003. № 46. Ст. 336). (Закон втратив чинність на підставі Закону N 2469-VIII (2469-19) від 21.06.2018). URL : https://zakon.rada.gov.ua/laws/show/975-15.

7. Про Збройні Сили України : Закон України від 6 груд. 1991 р. № 1934-XII. Відомості Верховної Ради Укрӓ̈ни (ВВР). 1992. № 9. Ст. 108). URL : https://zakon.rada.gov.ua/laws/show/1934-12.

8. Про Кабінет Міністрів України : Закон України від 27 лют. 2014 р. № 794-VII. Відомості Верховної Ради (BВP). 2014. № 13. Ст. 222. URL : https://zakon.rada.gov.ua/laws/show/794-18.

9. Про національну безпеку України : Закон України від 21 черв. 2018 р. № 2469-VIII. Відомості Верховної Ради (ВВР). 2018. № 31. Ст. 241. URL : https://zakon.rada.gov.ua/laws/show/2469-19.

10. Про оборону України : Закон України, від 6 груд. 1991 р. № 1932-XII. Відомості Верховної Ради Украӥни (ВВР). 1992. № 9. Ст. 106). URL : https://zakon.rada.gov.ua/laws/show/1932-12.

11. Про рішення Ради національної безпеки і оборони України від 6 травня 2015 р. «Про Стратегію національної безпеки України» : Указ Президента України від 26 травня 2015 року № 287/2015. URL : https://zakon.rada. gov.ua/laws/show/287/2015.

12. Публічне управління : термінол. слов. / уклад. : В.С. Куйбіда, М.М. Білинська, О.М. Петроє та ін. Київ : НАДУ, 2018. С. 192-193. URL : http://academy.gov.ua/pages/dop/150/files/ddb9f2c2-f166-4ebe89253f8cb99cec6d.pdf.

13. Хартія про особливе партнерство між Україною та Організацією Північно-Атлантичного договору від 09. лип. 1997р. Голос України. 11 лип. 1997 року. № 127(1627). URL : https://zakon.rada.gov.ua/laws/show/994_002.

\section{References:}

1. Kodeks povedinky stosovno voyenno-politychnykh aspektiv bezpeky [Code of Conduct on Military-Political Aspects of Security] \{Dzherelo: sayt OBSYE https:/www.osce.org/uk/node/253046?download=true\}. URL: https://zakon.rada.gov.ua/laws/show/994_116 
2. Konstytutsiya Ukrayiny [Constitution of Ukraine] pryynyata na p'yatiy sesiyi Verkhovnoyi Rady Ukrayiny 28 chervnya 1996 roku (Vidomosti Verkhovnoyi Rady Ukrayiny (VVR), 1996, № 30, st. 141). URL: https://zakon.rada.gov.ua/laws/ show/254k/96-vr [Ukraine]

3. Partnerstvo zarady myru Ramkovyy dokument. [«Partnership for Peace Framework Document»], vid 08.lyut. 1994 r. (Dyplomatycheskyy vestnyk. N 13 - 14. 1994. S. 32-33. ). URL: https://zakon.rada.gov.ua/laws/show/950_001

4. Pro Derzhavnu sluzhbu spetsial'noho zv"yazku ta zakhystu informatsiyi Ukrayiny, [About the State Service for Special Communications and Information Protection of Ukraine] Zakon Ukrayiny vid 23 lyut. 2006 r. № 3475-IV (Vidomosti Verkhovnoyi Rady Ukrayiny (VVR), 2006, № 30, st.258). URL: https://zakon.rada.gov.ua/laws/show/3475-15

5. Pro Derzhavnu spetsial'nu sluzhbu transportu, [About the State Special Transport Service] Zakon Ukrayiny vid 5 lyut. 2004 r N 1449-IV ( Vidomosti Verkhovnoyi Rady Ukrayiny (VVR), 2004, N 19, st.269). URL: https://zakon.rada.gov.ua/laws/show/1449-15

6. Pro demokratychnyy tsyvil'nyy kontrol' nad Voyennoyu orhanizatsiyeyu i pravookhoronnymy orhanamy derzhavy, [On Democratic Civilian Control of the Military Organization and Law Enforcement Agencies] Zakon Ukrayiny vid 19 cherv. 2003 r. N 975-IV(Vidomosti Verkhovnoyi Rady Ukrayiny (VVR), 2003, N 46, st. 336) \{Zakon vtratyv chynnist' na pidstavi Zakonu N 2469-VIII ( 2469-19) vid 21.06.2018\}. URL: https://zakon.rada.gov.ua/laws/show/975-15

7. Pro Zbroyni Syly, Ukrayiny [On the Armed Forces Ukraine] Zakon Ukrayiny vid 6 hrud. 1991 r. N 1934-XII (Vidomosti Verkhovnoyi Rady Ukrayiny (VVR), 1992, N 9, st.108). URL: https://zakon.rada.gov.ua/laws/show/1934-12

8. Pro Kabinet Ministriv Ukrayiny, [On the Cabinet of Ministers of Ukraine] Zakon Ukrayiny vid 27 lyut. $2014 \mathrm{r}$. № 794-VII, (Vidomosti Verkhovnoyi Rady (VVR), 2014, № 13, st.222). URL: https://zakon.rada.gov.ua/laws/show/794-18

9. Pro natsional'nu bezpeku Ukrayiny, [On the national security of Ukraine] Zakon Ukrayiny vid 21 cherv. 2018r. № 2469-VIII, (Vidomosti Verkhovnoyi Rady (VVR), 2018, № 31, st.241). URL:https://zakon.rada.gov.ua/laws/ show/2469-19

10. Pro oboronu Ukrayiny, [On Defense of Ukraine] Zakon Ukrayiny, vid 6 hrud. 1991 r. № 1932-XII (Vidomosti Verkhovnoyi Rady Ukrayiny (VVR), 1992, № 9, st.106). URL: https://zakon.rada.gov.ua/laws/show/1932-12

11. Pro rishennya Rady natsional'noyi bezpeky i oborony Ukrayiny vid 6 travnya 2015 r. «Pro Stratehiyu natsional'noyi bezpeky Ukrayiny», [On decision of the National Security and Defense Council of Ukraine of May 6, 2015 «On the Strategy of National Security of Ukraine»], Ukaz Prezydenta Ukrayiny vid 26 travnya 2015 roku № 287/2015. URL: https://zakon.rada.gov.ua/laws/show/287/2015

12. Publichne upravlinnya : terminol. slov. [Public administration: terminal. words.] / uklad. : V. S. Kuybida, M. M. Bilyns'ka, O. M. Petroye ta in. ; za zah. red. V. S. Kuybidy, M. M. Bilyns'koyi, O. M. Petroye. Kyyiv : NADU, 2018. S. 192-193. URL: http://academy.gov.ua/pages/dop/150/files/ddb9f2c2-f166-4ebe-8925-3f8cb99cec6d.pdf

13. Khartiya pro osoblyve partnerstvo mizh Ukrayinoyu ta Orhanizatsiyeyu Pivnichno-Atlantychnoho dohovoru vid 09. 1yp. 1997r. [Charter on the Special Partnership between Ukraine and the North Atlantic Treaty Organization of 9 July 1997] (Holos Ukrayiny, 11 lyp. 1997 roku, N 127 (1627). URL: https://zakon.rada.gov.ua/laws/show/994_002 